\title{
HANDEDNESS OF CHILDREN DETERMINES PREFERENTIAL FACIAL AND EYE MOVEMENTS RELATED TO HEMISPHERIC SPECIALIZATION
}

\author{
Carmina Arteaga', Adrián Poblano
}

\begin{abstract}
Background: Despite repeated demonstrations of asymmetries in several brain functions, the biological bases of such asymmetries have remained obscure. Objective: To investigate development of lateralized facial and eye movements evoked by hemispheric stimulation in right-handed and left-handed children. Method: Fifty children were tested according to handedness by means of four tests: I. Mono-syllabic non-sense words, II. Tri-syllabic sense words, III. Visual field occlusion by black wall, and presentation of geometric objects to both hands separately, IV. Left eye and the temporal half visual field of the right eye occlusion with special goggles, afterwards asking children to assemble a three-piece puzzle; same tasks were performed contralaterally. Results: Right-handed children showed higher percentage of eye movements to right side when stimulated by tri-syllabic words, while left-handed children shown higher percentages of eyes movements to left side when stimulated by the same type of words. Left-handed children spent more time in recognizing non-sense mono-syllabic words. Hand laterality correlated with tri-syllabic word recognition performance. Age contributed to laterality development in nearly all cases, except in second test. Conclusion: Eye and facial movements were found to be related to left- and right-hand preference and specialization for language development, as well as visual, haptic perception and recognition in an age-dependent fashion in a complex process.
\end{abstract}

KEY WORDS: handedness, language, haptic perception, visual perception, left and right hemispheres, brain specialization.

\section{La lateralidad manual determina la preferencia motora ocular y facial en relación con la especialización hemisférica en niños}

Resumen - Contexto: A pesar de las repetidas demostraciones de asimetría en varias funciones cerebrales, sus bases biológicas permanecen no bien conocidas aún. Objectivo: Investigamos el desarrollo de la lateralización de los movimientos faciales y oculares provocados por la estimulación hemisférica preferencial en niños diestros y zurdos. Método: Se examinaron 50 niños que se dividieron de acuerdo a su lateralidad manual, se les aplicaron 4 pruebas: I. Discriminación de palabras mono-silábicas sin-sentido, II. Palabras tri-silábicas con sentido III. Oclusión mono-ocular y discriminación táctil de figuras geométricas por cada mano. IV. Oclusión del ojo izquierdo y de la mitad temporal del campo visual derecho y después contralateralmente solicitando al niño armar un rompecabezas de 3 piezas. Resultados: Los niños diestros mostraron un mayor porcentaje de movimientos oculares hacia la derecha cuando se les estimuló con palabras trisilábicas, mientras los zurdos presentaron más movimientos oculares hacia la izquierda con el mismo tipo de palabras. Los niños zurdos usaron más tiempo para reconocer las palabras monosilábicas sin sentido. La lateralidad correlacionó con la discriminación de palabras trisilábicas. La edad contribuyó significativamente al desarrollo de la lateralidad en todas las pruebas excepto la segunda. Conclusión: Se encontró que los movimientos oculares y faciales se relacionan con la preferencia manual derecha-izquierda y con la especialización para el desarrollo del lenguaje, percepción táctil y visual de una manera dependiente de la edad.

PALABRAS-CLAVE: lateralidad, lenguaje, percepción háptica, percepción visual, hemisferios derecho e izquierdo, especialización cerebral.

Laboratory of Cognitive Neurophysiology. Nacional Institute of Rehabilitation, México City, México: 'MD, MSc, Audiologist, ${ }^{2} \mathrm{MD}$, MSc, DSc, Neurophysiologist.

Received 24 August 2007, received in final form 2 May 2008. Accepted 2 June 2008.

Dr. Adrián Poblano - Calzada Mexico Xochimilco 289, Col. Arenal Guadalupe, Deleg. Tlalpan, C.P. 14389-Mexico, D.F. - Mexico. E-mail: drdyslexia@starmedia.com 
Asymmetry in human cerebral hemisphere function, as reflected in a special relationship of the left hemisphere to language, has been recognized for more than a century'. Subsequent observations have identified other aspects of lateralization in brain tasks, such as the superiority of the right hemisphere for spatial manipulations. Despite repeated demonstrations of asymmetries in several functions, the biological bases of such asymmetries have remained obscure ${ }^{2}$. This aspect of brain organization, referred to as functional hemispheric asymmetry or functional specialization, is mainly noticeable in the human brain ${ }^{3}$. Most individuals ( $98 \%$ ) show right-hand preference for writing and other manual activities, which are related to cerebral dominance for language in the left hemisphere in $70 \%$ of the cases ${ }^{4}$. In the other hand, it has been noticed that left-handed subjects have differences in cognitive activities and significant asymmetries when compared with right-handed subjects ${ }^{5}$. Biological motion, especially facial motion, provides a rich and subtle source of information on many tasks, including subject and object recognition, facial speech, and the expression of emotion ${ }^{6,7}$. However, facial movements have been scarcely studied in relation to specific hemispheric stimulation. An evaluation of facial movement often plays a role in the assessment of patients with facial motor deficits, in planning facial reconstructive surgery ${ }^{8-10}$, and in a evaluation of neuropsychological functions associated with behavioral, language, and learning disabilities ${ }^{11}$.

Vision of the human face is an important stimulus for recognizing characteristics of every individual, as well as his/her gender, age and race, and identifying categorical human expressions like: annoyance, happiness, sadness or surprise $^{12}$. Visual perception depends among other variables, on the form of the object seen. It has been showed that control and visual actions are analyzed in 17 and 18 sensory cortical areas, respectively, when presentation of one object is unidimensional, thus preventing activation of all other areas in the visual cortex ${ }^{13}$; on the contrary, vision of one object in movement operates 18 and 19 Brodmann areas, respectively. The nasal segment of the visual field of every eye registers the temporal half of the corresponding retina, whereas the temporal region of the visual field registers the nasal half of the retina. In the central nervous system visual pathway, the fibers of the optical nerve that come from the temporal segment of the retina carry information to the same hemisphere, whereas the proceeding ones from the nasal segment of the retina interweave in the optical chiasma and cross to the other hemisphere ${ }^{14}$. Some evidences suggest that eye movements and covert attention may be mediated by complex cognitive mechanisms; for example, cognitive activity produced in one hemisphere can trigger eye movements in the contralateral side ${ }^{15}$; nonetheless, this evidence requires additional supporting research. Body laterality has distinguished human beings for centuries as a rather exclusive feature of man, in difference with many other species. The causes of this are under research and explanations vary from fetal position during pregnancy to faster maturation of one cerebral hemisphere ${ }^{3}$, these facts has been matter of research for many groups of neurologists.

Thus, in this study, we chose to investigate development in a short life-time period, facial and eye movements evoked by preferential hemispheric stimulation in a sample of right-handed and left-handed healthy school children. Our working hypothesis was: left-handed children have preference for eye and facial movements towards the left side of the face, whereas right-handed children more frequently show eye and facial movements towards the right side, and this effect will depend on age.

\section{METHOD}

\section{Subjects}

The sample was selected from healthy 8 to 10 year-old school-age children. We tested 50 school children from a public school with the following characteristics: age within the range quoted above, each participant demonstrating a normal neurologic examination ${ }^{16}$, with better than $20 / 20$ Snellen visual acuity, normal screening pure-tone audiometry, adequate familial environment (we included only children from integrated families, where both parents lived with the child), middle socioeconomic status, and Wechsler Intelligence Scale for ChildrenRevised in Mexico (WISC-RM Full Scale) $\geq 90^{17}$. Participant did not demonstrate attention deficit-hyperactivity disorder (AD$H D$ ), epilepsy, mental retardation, cerebral palsy, or other neurological disorders, psychiatric disorders, congenital malformations (such as those seen in children with Fragile $X$ syndrome) or stuttering. Children were divided in two groups according to handedness with the following equation: $100 \times([R-L] /[R+L])$ for right- or left-hand use preference ${ }^{18}$. Each group comprised 25 individuals. The Institutional Review Board of the National Institute of Rehabilitation in Mexico City approved the protocol and informed consent and signed forms were obtained from parents and children.

\section{Procedures}

We used the experimental design by Zaidel ${ }^{19}$. Children sat comfortably on a chair in front of a desk and were stimulated by means of a list of the most common Spanish words used in Mexico City area after Castañeda and Pérez-Ruiz ${ }^{20}, 20 \mathrm{~dB} \mathrm{HL}$ above hearing threshold. The list contained the phonetically-bal- 
Appendix. Mono-syllabic and tri-syllabic words lists.

\begin{tabular}{cc}
\hline $\begin{array}{c}\text { Mono-syllabic } \\
\text { no-sense words list }\end{array}$ & $\begin{array}{c}\text { Tri-syllabic sense words } \\
\text { list (translated) }\end{array}$ \\
\hline $\mathrm{Hul}$ & Borracho (Drunkard) \\
$\mathrm{Gu}$ & Capullo (Cocoon) \\
$\mathrm{Mi}$ & Ocupa (Busy) \\
$\mathrm{Go}$ & Seguro (Secure) \\
$\mathrm{He}$ & Capucha (Hood) \\
$\mathrm{Cra}$ & Helecho (Fern) \\
$\mathrm{Ju}$ & Aguja (Needle) \\
$\mathrm{Ye}$ & Viruta (Shaving) \\
$\mathrm{Yi}$ & Mocoso (Toddler) \\
$\mathrm{Da}$ & Resumen (Summary) \\
$\mathrm{Dro}$ & Arroyo (Stream) \\
$\mathrm{Mu}$ & Petaca (Suitcase) \\
$\mathrm{Pre}$ & Anoche (Last night) \\
$\mathrm{Hi}$ & Ocote (Little wood stick) \\
$\mathrm{Se}$ & Garrote (Big stick) \\
& \\
\hline
\end{tabular}

anced most common words. This test is customarily used to obtain word-recognition percentages in our country. Stimuli were delivered biaurally in free-field via loudspeaker using an Amplaid A-171 audiometer (Portland, OR, USA). Children were asked to recognize and respond aloud with the correct word. Word types utilized as test material were as follows: mono-syllabic non-sense, and tri-syllabic sense words and with this method were given mainly to the left hemisphere (Appendix).

Afterwards, the children's vision was occluded by a black wall that covered the full-visual field, and geometric objects were presented separately to each the right or the left hand for haptic hemispheric-prefer recognition. Children were asked to answer in recognition of each object, and correct answers as well as misspellings were recorded (Fig 1).

Next, the left eye and the temporal half visual field of the right eye were occluded with special goggles, and children were requested to assemble a three piece puzzle with the left hand. Afterward, the right eye was occluded as well as the temporal half visual field of the left eye, and the children were asked to perform the same assembly task with the right hand (Fig 2).

\section{Videotape recordings and analysis}

All tests were performed beginning with the ipsilateral side of the dominant hand in the Edinburg's test. Simultaneous videotape recordings of facial and eye movements while the subject performed each task were employed. Eye and facial movements were visually recorded only by the principal investigator blinded to group pertinance. Videotape recordings were conducted with the video camera located in front of the face at level of the

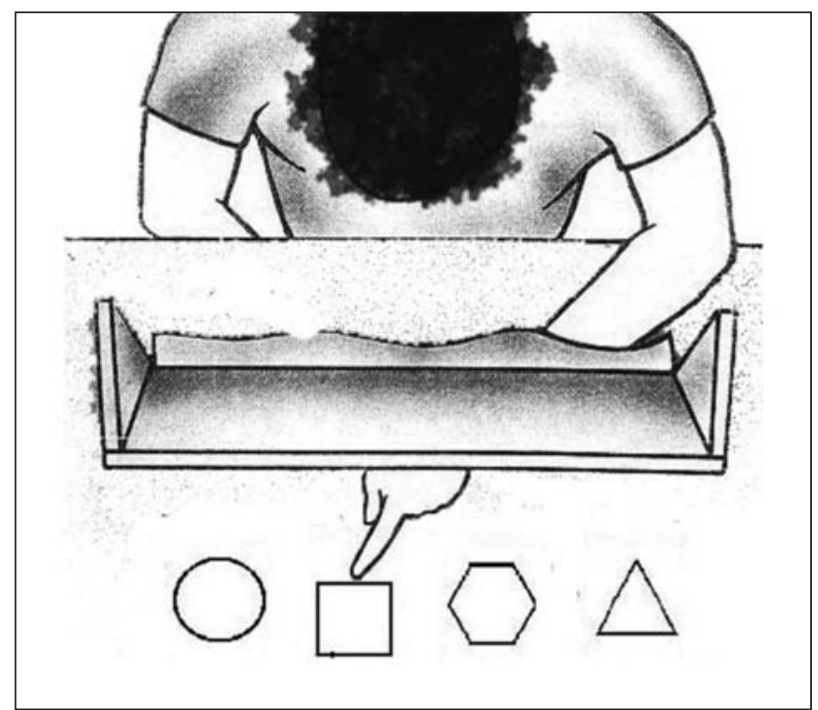

Fig 1. Design of the Haptic Recognition Test. Subject's visual field was occluded by the black wall. The subject was asked to recognized figures with each hand.

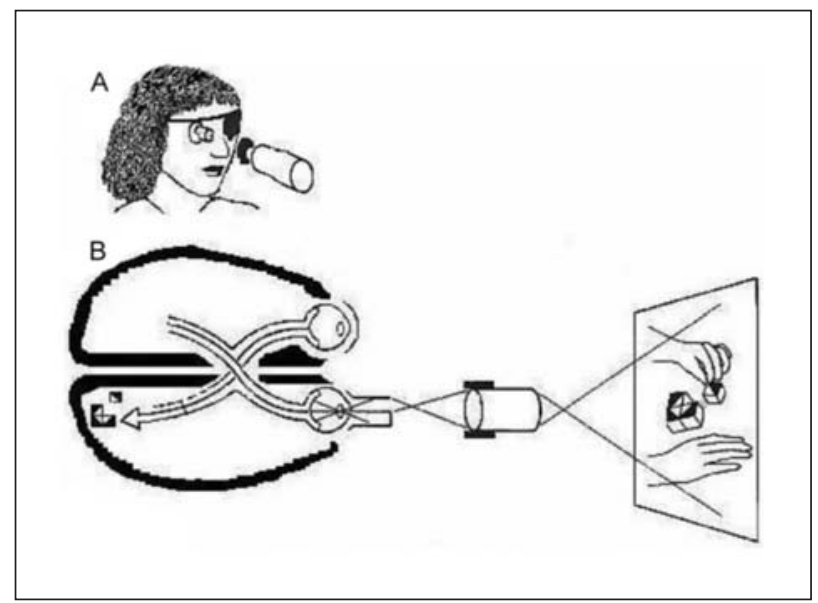

Fig 2. Selective Hemi-field Visual Recognition Test. Contralateral eye and temporal visual field was occluded while the subject used only the nasal hemi-field for puzzle assembly. (A) Design of special goggles. (B) Visual pathway between stimuli and occipital visual cortex.

nose, with the face uncovered and clean, without hair or glasses and with adequate brightness. Facial and eye movements in each test were evaluated using frame-by-frame slow motion of film recordings of 333-msec periods (Video Camera Recorder CCDTR350, Sony Corporation, Tokyo, Japan), in a VHS-HQ DA4 videocassette player (Goldstar, Seoul, Korea) in a JVC TV monitor (JVC, New Jersey, USA). Variables studied included the following: stretching of the mouth, (depressor labii inferioris movements, and elevation of labii superioris, orbicularis oris, and the zygomatic muscles) and lateral eye movements (rectus internus oculi, rectus externus oculi, obliquus superior muscle and obliquus inferior muscle) as binomial variables. No movements of the frontal region were observed during performance of four tests; 
therefore, none were included in the analysis. Subsequently, the latencies of each movement were calculated employing frameby-frame analysis as continuous variables.

\section{Statistics}

The mean and standard deviation (SD) of quantitative variables and the percentages of binomial variables were calculated. $\chi^{2}$ test was used to compare binomial variables frequency (percentages of eye movements to right and left side; and percentages of labial right and left movements). In addition, we compared quantitative variable averages were compared using Student's t test (eye and facial movements latencies in each condition). Logistic regression was used to investigate the influence of hand laterality on each test performance. ANOVA for repeated measurements was used, utilizing the test type as a level-four factor for each year of age of children and employing HuynhFeldt corrections for homosedasticity assessment. The $p$ value accepted $a$ priori for detecting differences was $p \leq 0.05$.

\section{RESULTS}

Twelve male and 13 female right-handed children were analyzed, while the left-handed group consisted of 11 male and 14 female children. Mean ( \pm standard deviation, SD) of age of right-handed children was $100.96 \pm 10.83$ months and of left-handed children, 109.76 \pm 11.50 months. Average of Edinburgh test quotients of right-handed children was 84.4, while of left-handed children was 22.

Percentages in each sub-test of preferent hemispheric stimulation yielded significant differences between both groups of children in discrimination of the tri-syllabic word test when comparing right and left eye movements, right-handed children demonstrated higher discrimination percentages (Table 1). Latencies of facial and eye movements in each preferent hemispheric stimulation sub-test are shown in Table 2. Left-handed children spent significantly more time in recognizing mono-syllabic words ( $t=-2.03, p=0.048$ ).

Using logistic regression, hand laterality correlated only with recognition of tri-syllabic words ( $r=0.489$, $p=0.027$ ). In ANOVA tests, we found evidenced for significant contribution of age to laterality within subjects in the mono-syllabic recognition test $(F=4.52, d f=1,4.62$, $p=0.041)$, geometrical figure recognition in the contralateral hand test $(F=6.16, d f=1,6.22, p=0.018)$, and puzzle assembly in the contralateral vision field test $(F=5.30, d f=1$, 5.60, $p=0.027)$.

\section{DISCUSSION}

Right-handed children exhibited higher percentages of eye movements to the right side when stimulated by tri-syllabic words, while left-handed children demonstrated higher percentages of eye movements to the left side when stimulated by tri-syllabic words. Left-handed children spent more time in recognizing mono-syllabic non-sense words. Hand laterality correlated with tri-syllabic word recognition performance. Age contributed significantly to laterality development in nearly all tests with

Table 1. Percentage of performance in each sub-test of specific hemispheric stimulation.

\begin{tabular}{|c|c|c|c|c|c|}
\hline & \multirow{2}{*}{$\begin{array}{c}\text { Movement } \\
\text { area }\end{array}$} & \multicolumn{2}{|c|}{ Right-handed } & \multicolumn{2}{|c|}{ Left-handed } \\
\hline & & Right (\%) & Left (\%) & Right (\%) & Left (\%) \\
\hline \multirow[t]{2}{*}{ Discrimination of mono-syllabic words } & Eye & 67.2 & 32.8 & 68.8 & 31.2 \\
\hline & Lip & 67.2 & 32.8 & 54.8 & 45.2 \\
\hline \multirow[t]{2}{*}{ Discrimination of tri-syllabic words } & Eye & $65.6^{*}$ & $34.4^{\star *}$ & $46.8^{*}$ & $53.2^{* *}$ \\
\hline & Lip & 62.0 & 38.0 & 57.2 & 42.8 \\
\hline \multirow[t]{2}{*}{ Recognition of geometric figures with contralateral hand } & Eye & 52.0 & 48.0 & 41.2 & 58.8 \\
\hline & Lip & 46.8 & 53.2 & 49.2 & 50.8 \\
\hline \multirow[t]{2}{*}{ Puzzle assembly with contralateral vision field } & Eye & 36.0 & 64.0 & 42.8 & 57.2 \\
\hline & Lip & 44.0 & 56.0 & 48.8 & 51.2 \\
\hline
\end{tabular}

${ }^{*} \mathrm{p}=0.021 ;{ }^{* *} \mathrm{p}=0.029$

Table 2. Latencies of facial and eye movements in each sub-test.

\begin{tabular}{ccccc}
\hline & Test 1 (ms) & Test 2 (ms) & Test 3 (ms) & Test 4 (ms) \\
\hline Right handed & 27.76 & 31.24 & 50.16 & 56.56 \\
Left handed & 31.84 & 34.32 & 64.64 & 56.36 \\
\hline
\end{tabular}


the exception of the tri-syllabic word recognition test. To our knowledge this is the first study which correlated facial and eye movements with brain lateralization.

Right-handed children showed higher percentages of eye movements to the right side due specialization of left hemisphere for language decoding. Many research articles support left hemisphere dominance for language recognition, including for example those performed by Steinmetz et al., who showed that planum temporale asymmetry correlated with hand dominance ${ }^{21}$, left-handed individuals had a lesser degree of leftward asymmetry than righthanded individuals, as revealed by magnetic resonance imaging (MRI). Recently Mäkelä et al., studied N-100 magnetoencephalographic (MEG) responses to constant-formant vowels and diphthongs with formant transitions: all the stimuli elicited prominent auditory $\mathrm{N}-100$ responses, but the formant transitions resulted in latency modulations specific to the left hemisphere ${ }^{22}$. As expected from a review of the literature and the investigations quoted above, left dominance for language in our right-handed children induced more right-side eye movements when sense words were used as stimuli; contrariwise, left-handed children showed greater frequency of left-side eye movements for language stimuli as a result of their incomplete left-hemisphere dominance for speech processing.

The longer time used in mono-syllabic non-sense words recognition by left-handed children may be attributed to incomplete left-hemisphere specialization and difficulties for mastering language, verbal fluency, or linguistic-processing speed, as has been proposed for children with language delay and developmental learning disorders ${ }^{23,24}$. Although the left-handed children studied are asymptomatic and exhibit good school performance, our data suggest that this group of children is at high risk for language-reading difficulties. On the other hand, Knetch et al., suggested that atypical hemispheric specialization for language is not associated with major impairments of linguistic faculties in healthy subjects ${ }^{25}$. Thus, additional research is need to lend support to this finding.

Hand laterality correlated with word recognition. This fact confirms previous data from the literature supporting the role of left-hemisphere specialization for language dominance in right-handed subjects, as shown by Wyllie et al., utilizing intracarotid amobarbital administration in the language-dominance test and its correlation with cortical stimulation ${ }^{26}$, and by Schwartz et al., during recordings of electroencephalographic activity after craniotomy of right-handed patients with epilepsy ${ }^{27}$. A study performed by Holloway et al., related the sensoriomotor response to hand dominance, patients were tested by means of sensory-motor hand preference and simultaneous functional magnetic resonance imaging (fMRI), and the authors observed that in the majority of the studied subjects, cortical activation was contralateral to the prefered hand ${ }^{28}$.

Hand-preference development has been shown to be age-dependent, especially in the earlier stages of childhood. For example, Curt et al. found in 765 pre-school children that hand-asymmetry distribution for one moving task and for a graphic test was mainly age-dependent ${ }^{29,30}$ as observed also by our data.

Development of handedness and lateralization, and the relationships of these abilities to additional bodily functions, is a complex and not well-known process ${ }^{31}$. For example, auditory perception and its relationship to other lateralized functions is not well known, but deserves more attention in future research.

This study presents some limitations, including the low number of subjects studied, and the cross-sectional study design employed, which could have been improved by the use of a prospective follow-up. These points merit additional attention in future works. Notwithstanding this, we learned that interactions between lateralization of eye and facial movements is a complex, age-influenced process, a process wich will be studied in greater detail in future works.

AKNOWLEDGEMENTS - The authors' thanks go to Lucia Vega B.Sc., Principal of the Republic of Swaziland School, for her help in this research and to Maggie Brunner, M.A., and Eduardo Castro-Sierra Ph.D. for their comments and help in the preparation of the English version of the paper.

\section{REFERENCES}

1. Searleman A, Porac C. Lateral preference patterns as possible correlates of successfully switched left hand writing: data and a theory. Laterality 2001;6:303-314.

2. Bear D, Schiff D, Saver J, Greenberg M, Freeman R. Quantitative analysis of cerebral asymmetries. Fronto-occipital correlation, sexual dimorphism, and association with handedness. Arch Neurol 1986;43:598-603.

3. Aboitiz F, Ide A, Navarrete A, et al. The anatomical substrate for language and hemispheric specialization. Biol Rev 1995;28:45-50.

4. Loring DW, Meador KJ, Allison JD, Wright JC. Relationship between motor and language activation using fMRI. Neurology 2000;54:981-983.

5. Portellano JA, Torrijos S, Martínez-Arias R, Vale P. Cognitive performance of right handed and left-handed persons on the Wechsler adult intelligence scale (WAIS-III) (in Spanish). Rev Neurol 2006;42:73-76.

6. Reis VA, Zaidel DW. Brain and face: communicating signals of health in the left and right sides of the face. Brain Cogn 2001;46:240-244.

7. Hill HCH, Troje NF, Johnston A. Range- and domain- specific exaggeration of facial speech. J Vis 2005;5:793-807.

8. Trotman CA, Faraway JJ, Silvester KT, Greenlee GM, Johnston LE. Sensitivity of a method for the analysis of facial mobility. I. Vector of displacement. Cleft Palate Craniofac J 1998;35:132-141.

9. Clark-Weeden J, Trotman CA, Faraway JJ. Three dimensional analysis of facial movement in normal adults: influence of sex and facial shape. Angle Orthodon 2001;71:132-140.

10. Trotman CA, Stohler CS, Johnstone LE. Measurement of facial soft tissue mobility in man. Clef Palate Craniofac J 1998;35:16-25. 
11. Condon WS. Microanalysis of sound films: a media for brain-behavior correlation (in Spanish). In: Duffy FH, Geschwind N. Dyslexia. A neuroscientific approach to clinical evaluation. Barcelona, España. 1988:115-145

12. Webster MA, Kaping D, Mizokami Y, Duhamel P. Adaptation to natural facial categories. Nature 2004:428:557-561.

13. Granel T, Goodale MA. Visual control of action but not perception requires analytical processing of object shape. Nature 2003;426:664-667.

14. Seki Z. A vision of the brain. Oxford, Blackwell Scientific Publishing. 1985.

15. Struthers G, Charlton S, Bakan P. Lateral orientation, eye movements and dichotic listening. Int J Neurosci 1992;66:189-195.

16. Touwen BCL. The neurological examination of the child with minor nervous dysfunction (in Spanish). Buenos Aires, Panamericana. 1986.

17. Weschler D. WISC-R Scale of intelligence revised for school level (in Spanish) Mexico City, Manual Moderno. 1981

18. Oldfield RC. The assessment and analysis of handedness: The Edinburgh inventory. Neuropsychologia 1971;9:97-113.

19. Zaidel DW. The functions of the right hemisphere (in Spanish). La Recherche 1984;4:504-513.

20. Castañeda GR, Pérez-Ruiz SJ. Phonetic analysis of common use-word lists in speech audiometry (in Spanish). Otorrinolaringol Mex 1991; 36:23-30.

21. Steinmetz H, Volkman J, Jänke L, Freund H-J. Anatomical left-right asymmetry of language-related temporal cortex is different in left- and right-handers. Ann Neurol 1991;29:315-319.

22. Mäkelä AM, Alku P, May PJC, Mäkinen V, Tiitinen H. Left-hemispheric brain activity reflects format transitions in speech sounds. Neuroreport 2005;16:549-553.
23. Poblano A, Valadez-Tepec T, Arias ML, García-Pedroza F. Phonological and visuo-spatial working memory alterations in dyslexic children. Arch Med Res 2000;31:493-496.

24. Herbert MR, Ziegler DA, Deutsch CK, et al. Brain asymmetries in autism and developmental language disorder: a nest whole-brain analysis. Brain 2005;128:213-226.

25. Knecht S, Dräger B, Flöel A, et al. Behavioral relevance of atypical language lateralization in healthy subjects. Brain 2001;124:1657-1665.

26. Wyllie E, Lüders H, Murphy D, et al. Intracarotid amobarbital (Wada) test for language dominance: correlation with results of cortical stimulation. Epilepsia 1991;3:156-161.

27. Schwartz TH, Ojeman GA, Haglund MM, Lettich E. Cerebral lateralization of neuronal activity during naming, reading and line-matching. Cogn Brain Res 1996;4:263-273.

28. Holloway V, Gadian DG, Vargha-Khadem F, Porter DA, Boyd SG, Connelly A. The reorganization of sensorimotor function in children after hemispherectomy. Brain 2000;123:2432-2444.

29. Curt F, Maccario J, Dellatolas G. Distributions of hand preference and hand skill asymmetry in preschool children: theoretical implications. Neuropsychologia 1992;30:27-34.

30. Dellatolas G, de Agostini M, Curt F, et al. Manual, skill, hand skill asymmetry, and cognitive performance in young children. Laterality 2003 8:317-338.

31. Golby JA, Poldrack RA, Brewer JB, et al. Material-specific lateralization in the medial temporal lobe and prefrontal cortex during memory ecoding. Brain 2001;123:1841-1854. 